\author{
JOLANTA KARBOWNICZEK ${ }^{\star}$ \\ Cracow, Poland \\ ORCID ID: https://orcid.org/oooo-ooo3-4746-3814
}

\title{
TEENAGERS TOWARDS PARENTS: REASONS FOR AND MANIFESTATIONS OF AGGRESSIVE AND VIOLENT BEHAVIOUR (RESEARCH REPORT)
}

\begin{abstract}
The article presents a report on empirical research on the issue of aggressive and violent behaviour of children towards parents against the background of family conditions, conducted in primary schools in Chelm, in the Lubelskie Voivodeship. This issue remains unsolved and requires reliable theoretical and methodological (re)interpretations. Family problems cannot be easily assessed in an objective manner. An obstacle in providing information about aggression and violence on the part of one's own children is usually the feeling of guilt experienced by the parents themselves. Dilemmas connected with the introduction of the young generation into the world of adults, with the education of children and young people, are one of the most important and difficult problems in social life. Quite often are we dealing with examples of helplessness of parents and educators in the face of pathological situations that take place in family and school environments, in peer groups, on the streets and housing estates of our cities.
\end{abstract}

Keywords: aggressive and violent behaviour; teenagers; parents; family environment; prevention.

\section{Introduction}

Aggression and violence are social phenomena irrespective of the class and culture, escaping social and moral control. There is no definite answer to the question on how to protect the young generation from them. The reason we made a decision

* PhD habil. Jolanta Karbowniczek, associate professor at the Ignatianum Academy, Faculty of Pedagogy, Institute of Educational Sciences, Krakow, Poland; e-mail: jkarbow@poczta.onet.pl. 
to research this issue was the adoption of assumptions of methodological realism, curiosity of details, focusing on phenomena that „others” skip, accumulation of discoveries in order to deepen understanding of phenomena related to the problem I am interested in. By conducting this research, I tried to broaden my field of knowledge.

The key task was to learn the reality, facts, phenomena and processes closely related to the subject I investigated. I paid attention to the facts, the course of processes and their conditions; I described, analysed and forecast the course of the phenomena that interest me, while trying to thoroughly understand their meaning. My intention was to go deeper into the issue of children's aggression and violence towards parents, which is a novelty not only in theoretical reconstructions but in empirical approaches. I diagnosed this phenomenon, its reasons, symptoms and effects. I analysed it against the background of family conditions.

While studying Polish and foreign literature on the presented issues, I have found that in Poland and other countries there is a great deficiency in undertaking this issue by scientists and a small scope of empirical research (Tesch, 1990; Berry, 1995; Mullender, 1996; Browne \& Herbert, 1999; Ackermann \& Pickering, 2002; Ross, 2003). The display of aggressive and violent behaviour of children towards parents is barely emphasized, shallowly depicted, even overlooked and ignored in Polish and international professional literature.

\section{Methods}

The subject of the study was an analysis of aggressive and violent behaviour used by children towards parents, determining areas of tension of these phenomena, types of negative interactions affecting the functioning of the family in its everyday life. The main goal was the diagnosis of families in the context of determining the nature, type and forms of these behaviours. The descriptive and explanatory goal was to show aspects of family aggression and violence with emphasis on negative behaviour of young people towards parents, to determine their conditions, symptoms and effects. The exploratory goal was an analysis of bad aggressive-violent behaviour manifested by the school-aged youth towards their parents. Additionally, the etiology and causes behind the behaviour along with effectiveness of prevention methods in order to create a system of help and support for families in the Lubelskie Voivodeship were investigated. When commencing formulating research questions, I tried to consolidate the existing knowledge on the presented issue, thoroughly studying the entire research procedure.

The main problem is included in the following question: What kind of aggressive and violent behaviour do adolescents display towards their parents? The formulation of the main problem gave rise to the following specific problems: 1 . What is the relationship between the family situation and the occurrence of aggressive and violent behaviour of children towards parents? 2. Are behaviour patterns, norms, 
values, attitudes, methods and styles of parenting dominating in families related to aggressiveness and violence among primary school students? 3 . What are the causes, conditions and effects of teenagers' aggressive and violent behaviour towards parents? 4. What form of support and assistance can families affected by the problem of aggression and violence on the part of their child receive?

For the problems the main hypothesis and working hypotheses were selected. The main hypothesis reads that adolescents may exhibit various types of aggressive and violent behaviour towards their parents, which pose a threat to the quality of the harmonious functioning of the family environment; the First hypothesis is there may be a significant correlation between the family situation, its disturbances and difficulties and the occurrence of children's aggression and violence against parents; the second hypothesis - patterns, norms, values and attitudes dominating in the family may be related to aggressiveness and violence manifested by teenagers towards their relatives, may intensify or weaken this type of behaviour; the third hypothesis - aggressive and violent behaviour displayed by teenagers towards parents can be triggered by various causes and factors conditioning them, they can cause a lot of physical, mental and emotional damage, and the results may have negative, short-term or long-term effects; the fourth hypothesis - there are many forms of support and assistance for families at risk of aggression and violence. In this empirical study I have also conceptualized and operationalized variables. When choosing variables, I started from theoretical assumptions (definitions, concepts) gradually moving to empirical assumptions. Due to the fact that aggressive and violent behaviour occurring in the family home and everyday life of students cannot be seen, we are dealing with an unobservable variable. To study it, it was necessary to translate the variables from the language of theory into the language of everyday experiences, thus I performed operationalization (processing the theory into the language of research) of variables.

Aggressive and violent behaviour occurring in the studied group of teenagers were considered a dependent variable in this study. The indicators of the dependent variable were sources, factors influencing the formation of aggressive and violent behaviours, causes and their types, manifestations, ways of preventing aggression and violence (rational argumentation, applying punishments, rewarding positive and ignoring negative behaviours of teenagers, "thinking aloud" trainings, developing empathy, modelling positive socio-moral attitudes), preventive programs, support and assistance. The family environment of the studied children was adopted as the independent variable). The indicators of the independent variable were family structure, number of children in the family, parents education, socio-economic situation, housing conditions, parental attitudes, parenting styles and methods, family upbringing atmosphere, parents cultural level, way of spending free time, conflicts and misunderstandings, the ability to solve life problems and difficulties, alcoholism, unemployment, poverty, aggression and domestic violence. I assumed that there are causal relationships between independent variables and dependent 
variables, which are an integral part of the phenomena that constitute domestic violence, and in particular the violence of children against parent.

The diagnostic survey method was used in the research. I selected the following research technique and questionnaire tools: questionnaire for parents, and questionnaire for students. The group was deliberately selected from families residing in the city of Chełm, located in the Lublin Voivodeship. Graduates of 3 primary schools presented various environments with diverse social status. Many families were covered by social assistance from the Municipal Family Support Centre. The study included families whose children attend municipal primary schools. Research was carried out in grades 6, 7 and 8 of several primary schools. The classes were selected based on information prepared by school councilors, considering those related to aggressive and violent behaviour in the family. Students from 13 to 15 years old participated in the study. The diagnosis also covered parents of students participating in the study. In the years $2017-2019$, I started to develop the research procedure and main research, which included a group of 184 students (grade 6-26 people, 7-83 people, $8-75$ people; including 95 girls and 89 boys) and a group of 183 parents.

\section{Aggressive and violent behaviour of children towards parents (parents' opinions) - empirical interpretation of the phenomenon}

In empirical research, I analysed and interpreted specific opinions about the phenomenon of aggression and domestic violence of two research groups - parents and their children - students of grades 6-8 from three primary schools in Chełm, and compared statements showing the interdependence of phenomena in statistical approaches. The first research group was 183 parents, including 158 women and 25 men. Research that involved respondents was conducted at school during meetings with headteachers of individual classes. The most numerous group of 108 respondents was constituted by people aged 37 to 47 . Analysing the level of parents' education, I found that among both, fathers and mothers, dominated vocational (39\%) and secondary (74.4\%) education. The structure of the family was important for research issues. Most primary school students -151 (82.5\%) were brought up in full families, the rest in incomplete (10.4\%), reconstructed (4.4\%), broken $(1.6 \%)$ and foster (1.1\%). When it comes to employment, most parents were working. The unemployed constituted $24 \%$ of the total number of respondents, while the others performed various works under contract for specific work and occasional work. The comparable ratio of mothers (70.5\%) and fathers (72.4\%) refers to those working in Poland, while the number of fathers employed abroad is twice as high as mothers. The number of unemployed mothers is twice as high as compared to unemployed fathers. The financial and housing situation of the surveyed families presents medium, low and very low income levels. The respondents spoke about 
the educational atmosphere in the family, the mood and relationships prevailing in the household, the relationship of parents to children and children to parents.

The emotional atmosphere is a dominant one, it is characterized by a huge intensification of non-family life, which in turn, generates tensions, triggers bad interactions and stress due to many unmet needs. Respondents commented on upbringing difficulties and threats occurring in the family home pointing to financial problems - low wages (47.6\%), alcohol abuse (16.9\%), long-term unemployment (10.8\%), aggression (10.0 \%), domestic violence (9.5\%) and serious illness (5.2\%). Particular attention was paid to those responses, which pointed out that a significant problem is alcohol abuse by one or both parents and systematic domestic violence. Social pathologies have a destructive effect on families, contributing to the emergence of dysfunctions, and thus contribute to the formation of behavioural disorders among teenagers. Admitting to improper attitudes, excessive work, numerous tensions, conflicts, improper educational styles, strict educational methods, committed educational errors created resistance and was a challenge for the respondents, as it is evidenced by the empty spaces left in the survey. In their responses, they emphasized very diverse and complicated educational situations regarding the attitudes and behaviour of teenagers. According to them, the occurrence of bad parent-child relationships and disturbed emotional and social contacts is affected by the appearance of aggressiveness and violence in the family environment. In the examined families, regardless of their social status, there were various events adversely affecting daily functioning, posing a threat to all family members.

I have diagnosed the situation in terms of the existence of aggression, different forms of violence, as well as other negative behaviours and ways of conduct. The obtained results are not satisfactory and show discrepancies. Out of the total number of respondents, 31 indicated upbringing difficulties with children, 26 indicated their aggressive behaviour towards siblings, 26 indicated aggressive behaviour towards them, 22 surveyed people mentioned domestic violence and 22 pointed out to over-using profanity and insults. We talk about the difficulties occurring in adolescents when their improper behaviour is not subject to ordinary educational procedures, if they do not respond to reprimands, the punishments are ineffective and the behaviour deviates from the recognized moral norms in society. Having reinterpreted the obtained analysis of research results, we can conclude that the main source of educational difficulties in this case are mistakes in upbringing, made by parents who confessed in their statements a lack of acceptance, overprotective attitude, overly demanding attitude, disregarding the main line of conduct, improper reward and punishment methods, fiercequarrels and conflicts. The disturbing phenomenon for the respondents is the fact that in recent years the number of behavioural disorders and risky activities have increased significantly among teenagers who, looking for patterns, goals in life and strong excitement, behave aggressively using various forms of violence. According to parents, this 
type of undesirable behaviour is taught in a variety of environments: family, peer groups, school, in the playgrounds, in the neighbourhood.

Wounded by life and disrupted functional situations, adults' mistakes, they look for a company where they will be appreciated, in a group of colleagues from the neighbourhood who, impressed by bad behaviour, aggression, foul language, intolerance, force them to try stimulants. It is also accompanied by personal tragedy, emotional anaemia, helplessness, fear. By observing parents, neighbours, peers, children learn the language (creating a kind of sloppy neologisms), copy negative behaviours, adopt wrong attitudes, bad habits and preferences. Among 183 respondents, 44 people $(24 \%)$ considered profanity as an abnormal behaviour observed in the neighbourhood, 39 people $(21.3 \%)$ mentioned aggression, and 36 respondents $(19.7 \%)$ alcoholism. Negative behaviours included the demoralization of minors (18 people $-9.8 \%$ ), while domestic violence (16 people $-8.7 \%$ ) and drug addiction (10 people $-5.5 \%$ ) were considered a threat.

In the opinion of parents, adolescents' behaviour gets off the charts when they litter and impoverish their language, use vulgar taunts, get frustrated, insult or threat other people, release tensions, are arrogant resistant All of these are signs of a rebellion of the weak psyche, complexes, and undervaluation. According to respondents, the occurrence of aggressive behaviour in children of adolescence is frightening. Parents pay attention to hooligan excesses, which are visible in homes, schools, on the streets and clubs. The age of the aggressors is getting lower and the behaviour increasingly violent. During the rebellion age against the authority of adults, adolescents turn to their peers who feel and think alike, although they know little about life. They dream, desire, and hurry to adulthood. The age of rebellion turns into the age of organizing teenagers against parents, grandparents, their laws, regulations, and customs. From here, the road to aggression, drunkenness, hooliganism and violence seems very simple. Parents in their answers pointed to a group of peers in whose surroundings their children feel comfortable, gain friendship, acceptance, recognition, understanding, have the opportunity to confide in their problems and life difficulties, which they often miss at home. If they do not find it in their peer groups, they feel lonely and unhappy. They reach for stimulants, are irritable, become unpredictable and dangerous in their actions.

Psychopatisation leads to frequent drinking and smoking problems, and stimulants begin to interfere the formation of social inhibitors. Children conspicuously disregard all norms of social coexistence, neglect their duties, tasks and obligations. Respondents pointed to the demoralization of teenagers, which in this case was manifested in the negation and rejection of values, norms and principles, the use of intoxicators and drugs. The first place is taken by the negative environment in which various forms of aggressive and violent behaviour of teenagers are manifested. Violence is loaded with anger, aggression and fury and is accompanied by rich forms of expression: screams, insults, hand movements, impulsive behaviour and fierce inflicting pain. Respondents in their statements paid 
special attention to attacks of fury, growing from the inside, accumulation, rage, causing suffering and damage, blocking of aspirations, failure to meet expectations. The next key issue requiring reliable parental responses was to identify the causes and manifestations of children's aggressive and violent behaviour. Young people, staring at telephones, smartphones, smartwatches, the Internet, computer games, inundated in cyberspace, scream, slam the door, or lock themselves in their rooms. Hostility and nervous tension pose a mutual problem. Parental responses to adolescent rebelious behaviour were investigated. Parents mostly try raising their voices - 109 people (42.2\%), wait for hissy fit to stop - 62 people (24\%), pretend indifference -26 respondents (10.1\%), show anger -21 people (8.1\%), feel helpless 21 respondents $(8.1 \%)$, or beat their children -19 people (7.4\%). In these cases, the listed situations become the causes of home quarrels, and the consequence of these events is the phenomenon of aggression and violent behaviour. Capriciousness, irritability, mood swings, talking back, overreacting, gaining more leverage, self-reliance are typical symptoms of a rebelious individual. In such cases, in my opinion, mutual valuation, understanding, constructive conversations, negotiations, attention, devoting more time, establishing educational boundaries and consistency in respecting them, as well as acceptance and support, are important.

\section{Aggressive and violent behaviour of children towards parents (opinions of teenagers) - empirical interpretation of the phenomenon}

The second group of respondents, students of grades 6,7 and 8 spoke about existential difficulties and social threats in their families. They were asked about the existence of verbal and physical abuse in their families. Out of the total number of respondents, 104 people $(56.5 \%)$ confirmed the difficulties and threats occurring in family homes (alcoholism, aggression, violence, severe illness, long-term unemployment), the remaining group of 80 people mentioned none of those. Research shows that not all families of respondents have a harmonious atmosphere. Alcohol abuse of the parents leads to degradation of family and personal life, causing suffering of the loved ones. Young people, observing the behaviour of their "drunk" parents, begin to drink themselves, become aggressive, enter the path of crime.

Respondents pointed out in their answers violence between parents, parental violence towards them and their attitudes towards violence. Disturbed social contacts, emotional instability, acts of active aggression, insults, coercion, injuries, stress compose continuous traumatic situations many children experience at home. The respondents complained about the poor economic status of families, unemployment, low income constituting a threat to meeting many of their basic needs and family functions, destroying peace. A history of severe illness of loved ones turned out to be a very serious problem, especially in families of alcoholics, in view of the „,vagueness" of work and functioning of the health service, and above 
all the expectations of help and support, systematic and effective treatment, queues to specialists, expensive medicine.

In the further part of the research, primary school students spoke about risky behaviours towards parents and siblings, referring to the impactful dysfunctionality of the family system. They listed negative events and various tragic situations, aggressive behaviour of parents, the use of violence, systematic quarrels and lack of total agreement, which they witnessed and participated in. The most common behaviours mentioned by 114 respondents (62\%) were quarrels with parents, the next ones were: quarrels with siblings -61 people (33.2\%), fisticuffs with parents and siblings (57 people $-31 \%$ ) and shouting and provocation (29 people $-21.2 \%$ ), total disagreement ( 32 people $-17.4 \%$ ), insulting parents ( 29 respondents $-15.8 \%$ ). We are dealing here with verbal and physical abuse. The youth indicated answers regarding parents' aggression towards each other (24 persons - 13\%), corporal punishment (22 persons $-12 \%$ ), and fights (21 persons $-11.4 \%$ ). The obtained data show that quarrels with parents and siblings as well as fisticuffs are becoming a disturbing phenomenon dominating in the surveyed families. They are the result of a lack of communication and understanding of mutual problems. They mainly concern the issue of satisfying the needs of students in grades 6, 7, and 8, acceptance of their behaviour, and on the part of parents firmly enforcing decisions.

Inappropriate relationship with the household members proves the inefficiency of the upbringing process in the family. In the further part of empirical research, respondents spoke about the places where they encountered the manifestations of aggression and violence. In the first place they indicated the family home (61 people $33.2 \%$ ), in the second-place peer groups ( 47 people $-18.5 \%$ ), third place ( 25 people $9.8 \%$ ) on the fourth was school ( 23 people $-9.1 \%$ ). In the behaviour of teenagers during meetings, libations, house parties with peers, neighbours, housemates and friends dominated vulgarisms (91 people $-49.5 \%$ ), followed by alcoholism ( 56 people $-30.4 \%$ ), aggressive behaviour (46 people $-25 \%$ ), demoralization of minors ( 32 people $-17.4 \%$ ), verbal violence ( 26 people $-14.1 \%$ ), legal highs and drug addiction (19 people - 10.3\%). Statistical data indicate that the mentioned environments are perceived as places where minors encounter these phenomena. Therefore, they can constitute a source of aggressive and violent behaviour of the studied youth. The manners of friends with whom respondents have frequent contacts also impact their behaviour. These vulgarities are heard every day at home, school, in the community, street, store, at the doctor's, in the parking lot, in various tense situations of nervousness, conversations, quarrels, fights, anger with parents and peers. Another form of bad behaviour is the consumption of alcohol, intoxicants, drugs and violence against household members. Deeper diagnosis of research topics was given by questioning students of grades 6,7 and 8 about whether they were victims of aggression and domestic violence. Of the 184 teenagers surveyed, $50(27.2 \%)$ of them answered in the affirmative, $96(52.2 \%)$ denied and the rest 38 people i.e. $20.7 \%$ did not give any answer. 
Having analysed the above data, we can once again state that the problem of aggression and violence occurring in the family home is becoming apparent. The respondents spoke about the parents' reactions to their manifestations of aggression and violence. According to children's reviews (84 people $-30.4 \%)$, their parents most often reacted to this type of behaviour by showing calmness, waiting for the teenagers to calm down, others showed anger ( 72 people $-26.1 \%), 56$ people $(20.3 \%)$ shouted, while helplessness was shown by 25 people (9.1\%). Corporal punishment was used by 20 people (7.3\%), while 19 people showed indifference, which is $6.9 \%$. The obtained data testify to the reasonable behaviour of most parents who tried to react to the aggression and violence of their children in silence, a climate of prudent conversations, allowing for resolution of conflicts. Other reactions of parents to this type of behaviour indicated by the respondents are ill-considered, they do not give any positive educational effects. They should be considered undesirable and threatening to the development of a child's personality, in particular the intellectual and socio-emotional sphere. The next step in my empirical proceedings was to examine the reaction of teenagers to parental bans. The most common reaction of respondents ( 81 people $-19.8 \%$ ) to parental bans was insult, 77 people, which is $18.9 \%$ expressed a different opinion, respecting the decisions of their loved ones, 60 respondents $(14.7 \%)$ expressed rebellion, 44 people (10.8\%) manifested their emotions with shouting and quarrels, 29 respondents (7.1\%) expressed aggression by throwing objects, 26 adolescents (6.4\%) destroyed things, 25 people (6.1\%) ignored their parents by disregarding their opinions, 24 students $(5.9 \%)$ threatened selfaggression, others fought with parents and siblings (17 people $-4.2 \%$ ), beatings (14 respondents $-3.4 \%$ ) and exhibited other behaviours (11 people $-2.7 \%$ ).

Research shows a wide variety of ways teenagers respond to parent bans that testify to their strong tensions and emotional instability, as well as manifestations of uncontrolled and undesirable behaviour. Their reactions can therefore be considered unpredictable and dangerous. Factors such as attacks on parents, blaming for the situation, interrogations, criticism, insulting parents, indicate the problems of respondents with self-regulation. Offending, from a psychological point of view, is an emotional manipulation and blackmail, sulking, avoiding contact, pouting and quiet days, rebelling your identity in opposition to parents. Offended children manifest their immaturity, not knowing how to respond to difficult situation differently. They want to force the other person to feel guilty, regret, withdraw from the decision, deny the deeds that caused someone's pain. In their responses, when describing the issue of disputes with parents, they most often emphasized that the crux of the problem remains unexplained, and the risk of conflict situations recurring is high in their opinion. A nervous atmosphere in the family can affect the youngsters' behaviour and emotional responses. This issue has been analysed. The obtained results evoke little optimistic reflections. Well, as many as 91 respondents (19.7\%) most often left home to calm down, 85 people (18.4\%) were offended, 65 respondents (14\%) showed resistance, 53 people (11.4\%) slammed the 
door with anger, 37 respondents (7.8\%) screamed and started quarrels, 22 students (4.8\%) destroyed things, 20 people (4.3\%) threatened to do something wrong while the others $(18$ people $-3.9 \%)$ tried to strike and passed incorrect information to schools that they were subject to corporal punishments and were brought up in pathological families. All presented behaviours are a manifestation of various forms of aggression and violence. They point outdomination, vandalism and the use of force. They indicate the fight against relatives. Respondents participating in the created "toxic" vision of the world have become impatient, perplexed, distracted, insecure. This toxicity of the immediacy of this "now" and „already", which is taught by the media, every day, often confusing life, exposure to information about acts of aggression, violence, crimes, killings, terrorism, banditry, disasters and accidents make it difficult for a young person to clearly distinguish good from bad or true from false. The phenomena I present are becoming common, they cover almost all areas of social life, and this type of behaviour manifested by teenagers has become an instrument of achieving advantage and dominance over parents. Respondents did not perceive their attitude as bad. Therefore, there are changes in their psyche that perpetuate the wrong patterns. In my opinion, their individual and personality traits are of great importance: reduced level of self-control, impulsiveness, difficulty concentrating attention, temperament, hyperactivity, and a tendency to react aggressively to various situations. Undesirable behaviours in this case - aggression and violence - trigger these actions, which are a form of control, as well as interference with the privacy of an adolescent. Our research shows that adolescents' negative attitudes are a reaction to what happens in the family home. It can be assumed that many family conflicts arise as a result of spontaneous aggression, which may be caused by accumulated frustrations. In addition, at home, as stated by two groups of respondents, the phenomenon of aggression and violence is associated with disturbed interpersonal relationships. In this case, the most explicit forms of adverse and risky behaviour can be seen between parents and children. These relationships are usually characterized by high aggression in verbal communication. Shouts, threats, quarrels, insults, fights, malicious gossip, vengeance, provocations are instrumentally used to achieve their own goals. Solving such problems in a family environment requires intensification of educational activities, control of internal impulses and conflict resolution without the use of force. Parents should, together with pedagogues and psychologists, diagnose pathological phenomena and apply remedies adequate to the problems in the specific environment.

\section{Comparative analysis}

This section characterizes the phenomenon of aggression and domestic violence in the context of manifesting such behaviour of children towards parents. Hypotheses regarding the interdependence of aggressive and violent behaviour in the family 
have been put forward and verified. The study used a nominal scale, for this reason a test for two groups of children and parents was used - chi independence test - . The zero hypothesis will be the hypothesis about the independence of aggression, and hence he violence of parents against children and children against parents is not dependent on each other and is not connected in any way. To measure correlations between parents and children, the phi - Yule ( $\varphi$-Yule ) coefficient was calculated.

The analysis shows that children and parents have a different attitude towards rebellion. The most divergent responses of adolescents and parents are „anger” and "raising voice/scream”. Adolescents perceive the raised parental voice as anger, which often goes hand in hand. There is a group of parents who get angry but at the same time explain the correct rules of behaviour. Therefore, the hypothesis was tested, supposing that the distribution of responses of children and parents is the same. Taking into account the statements of all respondents regarding the reaction of parents to children's rebellion, the first place was taken by: raising the voice and screaming (165) second - waiting for the difficult situation (146), third anger (93) fourth - helplessness (46), fifth - indifference (45), while the beating (39) is located at the end. The obtained empirical value of the chi-square test $\chi^{2}-$ 49.22 is greater than the critical value - 11.07, which leads to the conclusion that there are grounds to reject the null hypothesis. Therefore, the conducted research confirms the existence of a relationship between the studied variables, and thus the distribution of children's and parents , answers regarding the parents' response to rebellion on the part of children is the same. The $\varphi$-Yule amounts to 0.366 , so the strength of the relationship of aggression in terms of parents' response to rebellion on the part of children is moderate.

When it comes to how teenagers respond to bans, the responses of children and parents mostly overlap. The obtained empirical value of the chi-square test $\chi 2-22.90$ is greater than the critical value -14.07 , which leads to the conclusion that there are grounds to reject the null hypothesis. Therefore, the conducted research confirms the existence of a relationship between the studied variables, so the distribution of children's and parents' responses regarding the child's response to bans is the same. When analysing the correlations between parents and children, we calculate the value of the $\varphi$-Yule coefficient. It is 0.25 in this case, therefore, the strength of the aggression relationship in terms of the child's reaction to prohibitions is weak.

When analysing the results regarding the reaction of parents and children to quarrels and difficult life situations, it should be stated that the answers of children and parents mostly coincide. There are differences in the indications "coming out and slamming the door" and "coming out to calm down". Students in grades 6, 7, 8 more often marked rebellion and leaving home. Obtained empirical value of the chi-square test $\chi^{2}-21.459$ is greater than the critical value -18.31 , which leads to the conclusion that there are grounds to reject the null hypothesis. The research therefore confirms the existence of a relationship between the variables studied, so 
the distribution of children's and parents' responses regarding the child's response when they are upset by a conversation/quarrel with parents is the same.

Analyzing the correlations between parents and children, we calculate the value of the $\varphi$-Yule coefficient. In this case, it amounts to 0.242 , so the strength of the relationship of aggression in the child's response when he is upset by conversation / quarrel with parents is weak. As for the responses of the respondents to the refusal to comply, the responses of the two groups overlapped. The reaction of respondents to a refusal to comply with requests was analysed statistically. The answers of teenagers and their parents mostly overlapped. Children twice as often as parents said that they humbly accepted their decisions. Therefore, the hypothesis that the distribution of responses of the two groups of respondents was the same was tested. Obtained empirical value of the chi-square test $\chi^{2}-24.211$ is greater than the critical value -14.07 , which leads to the conclusion that there are grounds to reject the null hypothesis. Therefore, the conducted research confirms the existence of correlation between the studied variables, so the distribution of children's and parents' responses regarding the child's response to a refusal to comply with his or her requests is the same. The $\varphi$-Yule coefficient amounts to 0.257 , therefore the strength of the relationship of aggression in terms of the child's reaction in relation to the refusal to comply with his requests is weak.

When it comes to reactions and resistance to imposed decisions, the answers mostly overlapped. However, in two cases they were slightly different. Adolescents more than twice as often as parents responded to decisions with which they disagreed, reacted with rebellion and ignored the parents' decisions. Among other behaviours, they pointed to tantrums and throwing objects. Disturbing was the fact that the youngsters did not consider the opinions of their relatives. The conducted research confirms the existence of dependence and relationship between the studied variables, so the distribution of children's and parents' responses regarding the child's response to decisions with which they disagree is the same. When analysing the correlations between parents and children, the $\varphi$-Yule coefficient amounted to 0.43 , so the strength of the relationship of aggression in terms of the child's reaction to decisions with which he disagrees is moderate.

Regarding the impact of socioeconomic factors, support and assistance of specialists on the prevention of aggressive and violent behaviour of children towards parents, the responses of teenagers and their parents coincided in three cases, i.e. improvement of housing conditions, social assistance, support from the probation officer. Parents twice as often replied that the factors improving their relationships with adolescents are social competence workshops, school support, easier access to specialists. In turn, children twice as often uggested that their relationship with parents would be improved by financial support. The obtained empirical value of the chi-square test $\chi^{2}-49,572$ is greater than the critical value - 14.07, which leads to the conclusion that there are grounds to reject the null hypothesis. Therefore, the conducted research confirms the existence of dependence and relationship between 
the studied variables, so the distribution of children's and parents' responses in terms of factors improving the child's relationship with parents is the same. Again, the $\varphi$-Yule coefficient amounts to 0.368 , so the strength of the relationship in terms of factors improving the child's relationship with parents is average.

\section{Results discussion}

Research issues concerned the causes and manifestations of aggressive and violent behaviour of teenagers towards parents determined by family conditions. The empirical research allowed to formulate the following conclusions and verify hypotheses. There is a relationship between the family situation, its disturbances and difficulties, and the occurrence of children's aggression and violence against parents. The analysis of empirical research results gave rise to the conclusion that there is a relationship between the family situation, its disturbances and difficulties, and the occurrence of children's aggression and violence against parents. I treated aggression as incidental behaviour and violence as a process, assuming that aggression can lead to violence. Treating violence as a process, I considered the following criteria: imbalance of power between the perpetrator and the victim, the long-term nature of the phenomenon, cyclical behaviour and periods of their intensification. I examined the demographic and social situation of families, their structure, parents' education, employment, educational atmosphere at home, forms of domestic violence, aggressive behaviour of teenagers and their reaction to violence. Out of the obtained data, it can be concluded that the occurrence of various areas of aggressive tension in young people is associated with many family factors. The structure of the family, the employment of parents or one of them outside the place of residence, far from home affects reactions, causing negative behaviour. Low standard of living in the family was declared by $15.5 \%$ of respondents (difficult material situation - modal value), long-term unemployment was indicated by $8.4 \%$ of respondents, and alcohol abuse in the family by $12.5 \%$ of respondents. The occurrence of psychological or physical violence was a problem in the families of $10.9 \%$ of respondents. As many as $34.2 \%$ of the respondents often witnessed arguments at home. It can therefore be concluded that these are elements of significance for the occurrence of aggressive and violent behaviour growing up towards parents. Few parents also cared about forming emotional and spiritual bonds with teenagers. Young people (47\%) did not spend too much time with their parents, only with siblings, possibly with grandmother or other people, $30.4 \%$ of junior high school students had contact with alcohol, 49.4\% used vulgarisms, 10\% admitted to drug addiction. Among $39 \%$ of the youth there were aggressive and violent behaviours. It can therefore be concluded that the source of aggressive and violent behaviour of teenagers is the family home. It is worrying that young people do not always perceive their behaviour in terms of aggressive and violent areas of physical and mental stress. Research shows that $7.4 \%$ of parents surveyed 
were aggressive towards their children. They responded to any complex situations with a raised voice (42.3\%), indifference, helplessness, shouting, punching and slapping. Therefore, the hypothesis about the existence of a significant relationship between the family situation, its disturbances and difficulties and the manifestation of aggressive and violent behaviour of children towards parents was confirmed. Patterns of behaviour, norms, values and attitudes dominating in the family were related to aggressiveness and violence manifested by their relatives, intensified tensions and weakened this type of behaviour. The analysis shows that the studied families adversely affected the formation of positive personality traits of teenagers, not accepting their behaviour and not passing them any positive norms and values, as well as models, socio-moral attitudes and impeccable types of mutual interactions. Many of them have reproduced aggressive and violent behaviour from generation to generation. They applied punishments to children, forcing them to absolute obedience, critically condemning their manifested hostility, manifesting uncontrolled attacks of anger and hatred. By using this type of violence tactics in disputes and conflicts of life, they forced discipline and submission. It can therefore be concluded that the surveyed parents presented the wrong attitudes - rejection and avoidance, parenting (autocratic) styles, parenting methods (punishments), disregarding school successes, setting too high requirements, allocating excessive amounts of tasks, and requiring compliance with very strict rules. A comparative analysis of children and parents was also conducted, as a result of which I showed a relationship between parent-child and child-parent relationships. It shows that negative behaviours - aggression and violence of family members, punishments, consequences, parents' helplessness, struggling with complex and difficult life situations (experiencing escalating tensions) had a great impact on the behaviour of primary school students towards their parents and the environment. For all complex situations, 26 people (10.6\%) showed emotional indifference; 21 people $(8.1 \%)$ were angry; 127 people $(43.8 \%)$ punished teenagers by prohibiting them from using the Internet, telephone and television for a long time. The pattern of parents' responses was transferred to the respondents' behaviour and their immediate surroundings. Anxiety, withdrawal, noisiness, aggression and violence are symptoms that indicate the occurrence of high levels of stress in teenagers' behaviour. Behaviours intensifying aggression and violence of adolescents towards parents included: impulsiveness, explosiveness, increased conflict, irritability, rebellion, „mood swings", inability to deal with their emotions, frustrations, blackmail, intimidation, releasing tensions of brutality, indifference and anaesthesia, guardians' intolerance and manifestations of authority. In turn, the factors weakening these phenomena include: translation, mutual multidirectional dialogue, observation of behaviour, setting boundaries, tolerance, understanding, empathy, constructive resolution of difficult life situations, spending more free time with children, effectiveness and adequacy of punishment with offenses (forgiveness), prevention, therapy, support and assistance of specialists, institutions, organizations. The hypothesis 
is confirmed. Patterns, attitudes, norms and values dominating in the family were related to the manifestation of various forms of aggression and violence by teenagers towards their relatives (parents, siblings), intensified or weakened this type of behaviour. Aggression and violence of children towards parents has many causes and factors conditioning it, it can cause a lot of physical, psychological (emotional) damage, concerning the behaviour of the perpetrator and the victim, and disturb harmonious functioning among people.

Negative, short-term and long-term effects need also be mentioned. The research results prove that multiple and diverse factors were the most common causes of aggressive and violent behaviour of children towards parents: internal (genetic) irritability, indulgence, voltage response to stimuli, readiness for aggression and external (environmental, educational) - family, peer groups, local environment. Children exhibited physical (active) and psychological violence towards parents and siblings. Active physical violence was manifested by beating, punching, destroying objects, slapping, scuffing, jerking, kicking. Parents were forced to be submissive, covetous, or humiliated. They experienced psychological violence in the form of abuse: ignoring, rejecting, humiliating, imposing specific views, mocking, and embarrassing. Other reasons were low socioeconomic status, conflicts, alcoholism, unemployment, negative authorities, social isolation, disturbed emotional contacts between parents and children, resulting primarily from improper upbringing, frustrations, leniency, parents showing excessive tolerance towards aggressive children, aggressive manifestations attitudes of parents towards each other, teenagers and other people, approval of violent behavioural patterns, disrespect, contempt, a sense of failure. The physical and psychological violence exhibited by the respondents was accompanied by verbal aggression expressed by shouting, profanity, quarrels, threats and relational aggression - gossiping, false rumours. The effects of aggressive and violent behaviour of teenagers towards parents were: inability to make contacts, intensifying areas of difficult emotional tensions, ambivalence of feelings, blockade in fulfilling social and family roles, anxiety, sleep disorders, mood disorders, passive behaviour (closing in self-submission), pressure, shame, anger, avoidance of other people, disregarding oneself, lack of mutual understanding, reduced self-esteem, hopelessness, problems with building trust in loved ones. Qualitative and quantitative analysis of the tests we carried out confirmed the hypothesis. There are many forms of support and assistance for families at risk of aggression and violence manifested by their loved ones. In order to verify this hypothesis, respondents' needs were examined in terms of the possibility of using the support of specialists and social institutions. This hypothesis was confirmed. From the obtained data, it can be concluded that social culture, the strategy of actions adopted at individual levels of local government as well as at the level of national policy play an important role in solving problems of domestic violence. Access to many specialists largely determines the improvement of a child's relationship with parents. They can support family activities in the area 
of education and prevention. Thanks to the work of a psychologist, pedagogue, therapist, it is easier for a child to solve problems related to functioning in the modern world. Workshops for parents play an important role. These types of classes help to understand the problems of social pathology, prevention, mental health, social communication, which are so much needed in the education of a young person. The respondents also pointed to social assistance and meetings with the probation officer, the police and the school. Establishing interdisciplinary teams to support families in which domestic violence occurs has become extremely useful. I paid special attention to the opinions of the respondents regarding their financial and housing conditions. Good social conditions contribute to creating a child's atmosphere and conditions for development. The adopted local government strategy, an organised team of specialists were $\mathrm{f}$ an important factor improving the relationship of teenagers with parents or $17.7 \%$ of respondents. Parental competence workshops were very necessary for $16.7 \%$ of respondents, while $14.3 \%$ of respondents benefited from school support. There are many ways to prevent aggression, of which the most effective has been shaping the right social attitudes in all educational environments. Changing parents' inappropriate attitudes and behaviours effectively prevents outbreaks of anger and physical aggression among young people. Of the total number of respondents, $38 \%$ said that parental competence workshops would improve "parent-child" relationships. Teaching empathy to the teenagers, coping with stress, increasing self-esteem and aggression prevention training bring real behavioural changes. Respondents, as a support in the process of bringing up junior high school students, pointed to easier access to specialists (psychologist, pedagogue, therapist) and specialist consultations (42\%). A large number of teenagers (25\%) emphasised the importance of financial support, which they believe would significantly improve relationships with parents. Adolescents exhibited various types of aggressive and violent behaviour towards their parents, posing a threat to the quality of functioning of the whole family environment.

\section{Conclusions}

I consider the problem of manifesting various forms of aggressive and violent behaviour of children towards parents extremely important at both the family and society levels. Resisting and disobedience are usually seen as a particularly embarrassing behaviour for parents. Adolescents become fractious towards authorities. They are resistant, they do not comply with accepted norms and principles. They are characterised by perversity and arbitrariness, derive satisfaction from provoking adults, show aggression and violence, are unable to control frustration, have problems at school, have serious problems in social relations. They also react poorly to reinforcements and social punishments. Parents, in turn, in such cases consistently punish them for bad behaviour, using threats, criticism, humiliation, and reprimands. They give instructions with an irritated 
tone, presenting a tense and threatening attitude, ready to intervene in the event of failure to perform domestic and school duties, distancing themselves by introducing elements of long-term emotional anaesthesia. In many situations, they become helpless and unsteady in their educational activities. Considering the occurrence of this type of events, one should take care of and early intervention of those individuals who behave aggressively and use violence. The basis for solving such complex social problems is helping families to rebuild proper relationships and supporting their actions in order to activate positive behaviours, role models for future generations.

\section{References}

Ackermann, J.R., \& Pickering, S. (2002). Zanim będzie za późno: przemoc i kontrola w rodzinie. Gdańsk: GWP.

Anooschian, L.J. (2005). Violence and aggression in the lives of homeless children: A review. Aggression and Violent Behaviour, 10(2), 129-152.

Bandura, A. (2016). Style radzenia sobie ze stresem przez szkół gimnazjalnych doświadczających przemocy rówieśniczej. In W. Poleszak (Ed.), Wyzwania i zagrożenia adolescencji. Lublin: Innovatio Press.

Bereźnicka, M. (2014). Wychowanie dziecka we współczesnej rodzinie. Kraków: WNUP.

Berry, D.B. (1995). Domestic Violence Sourcebook. Los Angeles: RGA Groups.

Browne, K., \& Herbert, M. (1999). Zapobieganie przemocy w rodzinie. Warszawa: PARPA.

Danielewska, J. (2002). Agresja u dzieci - szkoła porozumienia. Warszawa: WSiP.

Dubis, M., \& Karbowniczek, J. (2018). Youth in View of the Issue of School Violence. European Scientific Journal, 8(14), 70-84.

Grochulska, I. (1993). Reedukacja dzieci agresywnych. Warszawa: WSiP.

Karbowniczek, J., \& Okoński, G. (2018). Zachowania agresywne i przemocowe dzieci wobec rodziców - napięcia, interakcje, (re)interpretacje działań (zarys problematyki). Chełm: PWSZ.

Kmiecik-Baran, K. (1998). Przemoc wobec dzieci - diagnoza i interwencja. In J. Papież, A. Płukis (Eds.), Przemoc dzieci i młodzieży w perspektywie polskiej transformacji ustrojowej. Toruń: Marszałek.

Komendant-Brodowska, A. (2014). Agresja i przemoc szkolna. Raport z badań. Warszawa: IBE.

Mazur, J. (2006). Przemoc w rodzinie, teoria i rzeczywistość. Warszawa: ŻAK.

Mellibruda, J. (2009). Przeciwdziałanie przemocy domowej. Warszawa: PTP.

Miłkowska-Olejniczak, G. (1996). Kto rządzi w polskiej szkole? - czyli o agresji dzieci i młodzieży w sytuacjach szkolnych. In M. Dudzikowa (Ed.), Nauczyciel uczeń. Między przemoca a dialogiem: obszary napięć i typy interakcji. Kraków: Impuls. 
Mullender, A. (1996). Rethinking domestic violence: The social work and probation response. London: Routledge.

Pagelow, M.D. (1984). Family Violence. New York: Praeger Publishers.

Pospiszyl, I. (1994). Przemoc $w$ rodzinie. Warszawa: WSiP.

Pospiszyl, I. (1999). Razem przeciw przemocy. Warszawa: ŻAK.

Pyżalski, J. (2012). Agresja elektroniczna i cyberbullying jako nowe ryzykowne zachowania młodzieży. Kraków: Impuls.

Ross, D.M. (2003). Childhood Bullying, Teasing, and Violence: What School

Personnel, Other Professionals, and Parents Can Do. Second Edition. Alexandria:

American Counseling Association.

Sherman, L.W., Schmidt, J.D, \& Rogan, D.P. (1992). Policing Domestic Violence:

Experiments and Dilemmas, New York: Free Press.

Surzykiewicz, J. (200o). Agresja i przemoc w szkole. Warszawa: CMPPP.

Tesch, R. (1990). Qualitative Research: Analysis Types and Software Tools, London

- Philadelphia: Falmer Press.

Urban, B. (2012). Agresja młodzieży i odrzucenie rówieśnicze. Warszawa: PWN.

Wolińska, J.M. (200o). Agresywność młodzieży. Problem indywidualny i społeczny.

Lublin: UMCS.

Wołk-Łaniewska, A. (1997). Zbrodnia i kara. Przegląd Tygodniowy, 3, 7-8.

\section{NASTOLATKI WOBEC RODZICÓW - PRZYCZYNY I PRZEJAWY ZACHOWAŃ AGRESYWNYCH I PRZEMOCOWYCH (RAPORT Z BADANIA)}

Streszczenie: $\mathrm{W}$ artykule przedstawiono raport $\mathrm{z}$ badań empirycznych dotyczących problematyki zachowań agresywnych i przemocowych dzieci wobec rodziców na tle uwarunkowań rodzinnych, prowadzonych w szkołach podstawowych na terenie województwa lubelskiego. Jest ona ciągle otwarta i wymagająca rzetelnych (re)interpretacji teoretyczno - metodologicznych. Problemy rodzinne niełatwo poddają się obiektywnej ocenie. Przeszkodą w udzielaniu informacji na temat agresji i przemocy ze strony własnych dzieci jest zwykle poczucie winy, którego doświadczają sami rodzice. Dylematy związane $\mathrm{z}$ wprowadzeniem młodego pokolenia w świat ludzi dorosłych, z wychowaniem dzieci i młodzieży, bywają jednym z najważniejszych i najtrudniejszych problemów życia społecznego. Dość często mamy do czynienia z przykładami bezradności rodziców i pedagogów wobec patologicznych zjawisk, mających miejsce w środowiskach: rodzinnym, szkolnym, w grupach rówieśniczych, na ulicach i osiedlach naszych miast.

Słowa kluczowe: zachowania agresywne i przemocowe; nastolatki; rodzice; środowisko rodzinne; profilaktyka. 